Original Article

Artigo Original

\title{
Parental perspectives of children using cochlear implant
}

\section{Perspectivas dos pais de crianças usuárias de implante coclear}

\author{
Marcela Roselin Stefanini ${ }^{1}$ \\ Marina Morettin ${ }^{2}$ \\ Julia Speranza Zabeu ${ }^{1}$ \\ Maria Cecília Bevilacqua ${ }^{3}$ \\ Adriane Lima Mortari Moret ${ }^{4}$
}

Keywords

Child

Cochlear Implantation

Family Relations

Descritores

Criança

Implante Coclear

Relações Familiares
Correspondence address:

Marina Morettin

Centro de Pesquisas Audiológicas do

Hospital de Reabilitação de Anomalias Craniofaciais

Rua Silvio Marchione, 3/20, Caixa Postal 620, Bauru (SP), Brasil, CEP: 17043-900.

E-mail: cpahrac@usp.br

Received: 07/21/2014

\begin{abstract}
Purpose: To evaluate the parents' perspective with regard to evolution of their child with cochlear implant (CI). Methods: This was a cross-sectional prospective study conducted at the Centro de Pesquisas Audiológicas of Hospital de Reabilitação de Anomalias Craniofaciais of Universidade de São Paulo. The selection of the sample was performed from the spontaneous demand, among the months from July to December 2011. The final sample comprised 50 parents or guardians of children using CI, with minimum 1 year and maximum of 3 years of device use. The translated and adapted to Brazilian Portuguese version of the questionnaire "Perspectives of parents of children with cochlear implants" was applied. This instrument consists of 74 questions and allows quantification of the parents' perspective on subscales that illustrate the situation of the child and family. Each question has five options scored from one to five responses. The Spearman test for comparison of results between the subscales was applied. Results: The social relationships, self-sufficiency, and communication subscales showed the highest mean score, whereas the worst score was for child support subscale, reflecting the independence and autonomy of the patients. The correlation between the child subscales was realized, and the results showed themselves significant and positive for communication subscale of communication with all others subscales. The family subscales also had a positive correlation with the communication, education, and self-sufficiency. Conclusion: These results demonstrate that parents have good expectations regarding communication, independence, and social participation of children after CI surgery, and this questionnaire is a useful tool for use in clinical practice.
\end{abstract}

\section{RESUMO}

Objetivo: Avaliar a perspectiva dos pais em relação ao implante coclear (IC) sobre a evolução da criança usuária do IC. Métodos: Tratou-se de um estudo prospectivo transversal desenvolvido no Centro de Pesquisas Audiológicas do Hospital de Reabilitação de Anomalias Craniofaciais da Universidade de São Paulo. A seleção da casuística foi realizada a partir da demanda espontânea entre os meses de julho e dezembro de 2011. A amostra final foi composta por 50 pais ou responsáveis de crianças usuárias de IC com no mínimo um ano e máximo de três anos de uso do dispositivo. Foi aplicado o questionário Crianças com implante coclear: perspectivas dos pais, traduzido e adaptado para o Português Brasileiro. Este instrumento é composto por 74 questões e permite a quantificação da perspectiva dos pais em subescalas que ilustram a situação da criança e da família. Cada pergunta apresenta cinco opções de respostas pontuadas de um a cinco. Foi aplicado o Teste de Spearman para comparação dos resultados entre as subescalas. Resultados: As subescalas relação social, autossuficiência e comunicação foram as que apresentaram maior média de pontuação. Já a pior pontuação foi da subescala de apoio à criança, reflexo da independência e autonomia dos pacientes. Quando realizada a correlação entre as subescalas relacionadas à criança, observou-se resultado estatisticamente significante e positivo da subescala de comunicação com todas as demais. As subescalas da família também apresentaram correlação positiva com a comunicação, educação e autossuficiência. Conclusão: Estes resultados demonstram que os pais apresentam boas expectativas em relação à comunicação, independência e participação social da criança após a cirurgia de IC, sendo este questionário uma ferramenta útil para uso na prática clínica.

Study carried out at the Audiological Research Center of the Hospital for Rehabilitation of Craniofacial Anomalies, Universidade de São Paulo - USP - São Paulo (SP), Brazil.

(1) Speech Language Pathologist by School of Dentistry of Bauru, Universidade de São Paulo - USP - Bauru (SP), Brazil.

(2) Graduate Program in Public Health at School of Public Health, Universidade de São Paulo - USP - São Paulo (SP), Brazil.

(3) Graduate Program at School of Dentistry of Bauru, Universidade de São Paulo - USP - Bauru (SP), Brazil. (4) Graduate Program at Hospital for Rehabilitation of Craniofacial Anomalies, Universidade de São Paulo USP - Bauru (SP), Brazil.

Conflict of interests: nothing to declare. 


\section{INTRODUCTION}

The use of cochlear implant (CI) in children provides important benefits for the development of listening and communication skills and allows their progress in school and, later on, in the ability to obtain, maintain, and perform a professional occupation. As a result, many children in the world have been receiving the $\mathrm{CI}^{(1,2)}$.

The success of this intervention depends on many factors. Among the factors related to family, the parental expectations and the support resources provided by them to the children in the acquisition of listening and language experience, in addition to the dynamics of social relations within the family and with other relatives, play an important role ${ }^{(3)}$.

Most researches in the area have explored the results of CI under a professional perspective, involving measurements concerning the perception and production of speech and communication skills; however, comparatively, many studies have examined the implantation process through the perspective of the family and parents. Similarly, it is observed that, although a series of objective and subjective tests are performed in CI services in order to evaluate the progress of children, it is the parents who may best assess the results and impacts of the device in their lives ${ }^{(4,5)}$.

The records of parental comments along with other evaluations (subjective and objective ones), which provides valuable information on the functionality of the child, the implementation process, the necessary additional intervention, and the benefits and limitations experienced, may help the CI service team and the ones responsible for the formulation of public policies in this area ${ }^{(6)}$. This way, the use of the questionnaires for the evaluation of the results, along with the objective tests, is increasingly available ${ }^{(7)}$.

The "Children with cochlear implants: parental perspectives" questionnaire is one of the instruments used. Developed by Archbold et al. in 2002 from the answers of 30 parents of children with CI (after 3 years of use of the device), involving themes related to both the child and the family, it was characterized as an instrument capable of raising the considerations of parents themselves, besides being applicable to large groups of deaf children and their families, in order to assess the impact of the $\mathrm{CI}^{(8)}$. Another study that identified the reliability of the instrument also noticed that it is capable of eliciting the parental point of view in a significant way ${ }^{(9)}$. In Brazil, this instrument was translated and culturally adapted as "Crianças com implante coclear: perspectivas dos pais", and it was verified, in its application, whether the CI improved the quality of life of the children from the assessed families ${ }^{(10)}$.

Thus, considering that the goals and wishes of parents must be taken into account during the planning of the therapeutical process $^{(11)}$ and on the establishment of long-term goals, allowing psychological and social adjustment, school performance, and future employment options for the child ${ }^{(12)}$, this study evaluated the parental perspective in relation to $\mathrm{CI}$ on the evolution of the child. It is believed that parents have to be recognized as important evaluators of the services and a valuable source of information on the quality of life, guiding the allocation of procedures of listening (re)habilitation ${ }^{(3)}$.

\section{METHODS}

This is a prospective cross-sectional study with random sampling, investigated and developed by the Audiological Research Center (Centro de Pesquisas Audiológicas - CPA) of the Hospital de Anomalias Craniofaciais, Universidade de São Paulo (HRAC/USP), campus Bauru, in São Paulo. This study was approved by the Ethics in Research Committee of the Institution (research protocol No. 181/2011).

\section{Case study}

Parents and legal guardians of children with CI, enrolled in the Audiological Research Center (CPA) of the HRAC/USP, were invited to take part in the research, regardless the model and the brand of the CI used.

The sample was selected randomly from the spontaneous demand of the CPA, inviting parents who attended the routine follow-up with their children during the period of July to December 2011, following the previously established criteria.

\section{Inclusion and exclusion criteria}

The inclusion criteria were to use children from at least one up to 3 years and 11 months of device use. The exclusion criteria included the presence of associated impairment (global development disorder, mild mental impairment, cerebral palsy, and other intercurrences revealed only after infantile development); presence of auditory neuropathy spectrum disorder; reimplantation of the internal device cases; and diagnosis of meningitis.

On average, 750 patients were seen in this period; however, considering the inclusion and exclusion criteria of the study, the case study consisted of 50 parents and legal guardians of children with CI. All participant families signed the Informed consent.

\section{Procedures}

For the investigation of the social and demographic variables of this population, the school education and socioeconomic level of the parents, the child's gender, the etiology of deafness, the age of the child at the time of the evaluation, the time of sensorial deprivation, the age of CI surgery, the open field audiometry, literacy, and the holding of Speech Language and Audiology Therapy were analyzed from the data recorded in the child's medical chart. It is noteworthy that the CPA/USP has a standardized and validated chart, which can be used as research material.

In the parental perspective evaluation in relation to the CI, we used the "Crianças com implante coclear: perspectivas dos pais" questionnaire, translated and adapted into Brazilian Portuguese ${ }^{(10)}$, originally developed as "Children with cochlear implants: parental perspectives"(8).

This instrument consists of 74 nongrouped affirmative and negative phrases, divided into subscales regarding the child and their family. The subscales regarding the child include the following investigation themes: communication, functionality, 
autonomy, well-being and happiness, social relations, and education. The subscales related to family consider implementation effects, support to the child, decision making, and the implementation process. Of all the questions, 48 of them are quantitative and 26 qualitative ones.

The authors ensured that the parents themselves answered the questionnaire, without the aid of the Speech Language Pathologist. In Brazil, many times, the patient or the family has difficulties in filling it out on their own. Thus, its use with the help of the researcher was performed to minimize reading and interpretation difficulties. The interviewer read each phrase slowly and without using synonyms or any kind of explanation in other words, to avoid misinterpretations and change of meaning of the phrases.

Parents were requested to accompany the reading of the questionnaire (they were handed in a copy) and marking the corresponding answer that was closer to their judgment from the Likert scale, which covers the following options: strongly agree $(\mathrm{SA})$, agree $(\mathrm{A})$, neither agree nor disagree $(\mathrm{N})$, disagree (D), and strongly disagree (SD).

After applying the questionnaire, the answers were scored from 1 to 5 , according to the scale: SA is worth $1 ; \mathrm{A}, 2 ; \mathrm{N}$, 3 ; D, 4; and SD, 5. The scores were obtained by a computer software provided by the Ear Foundation.

For each subscale, a percentage value was produced, ranging from $-100 \%$ to $100 \%$. Thus, the higher the score, the more positive the parental point of view.

As two subscales of the questionnaire - implementation process and decision to implement - have qualitative items, impossible of being numerically coded, they were excluded from the final analysis.

\section{Statistical Analysis}

The descriptive analysis of the sociodemographic and audiological variables of this population was performed.

The descriptive analysis of the results of the "Crianças com implante coclear: perspectivas dos pais" questionnaire, by subscale, was performed through the medians, the percentage means, the first quartile, the third quartile, the minimum and the maximum values. Besides, the distribution analysis was performed (\%) between the answers categories of each subscale in order to identify the strength of parental opinion in each item.

To verify the correlation between the subscales of the questionnaire, the Spearman correlation test was used, and the connection of the subscales to the following variables was identified: age at the time of the surgery, age at the evaluation, time of use of CI, time of sensorial deprivation, open filed audiometry mean, speech detection threshold (SDT), socioeconomic, and parental school education classification. The significance level of 5\% was adopted.

\section{RESULTS}

From the 50 questionnaires completed, $90 \%$ of them were filled out by the mothers, $8 \%$ by the fathers, and $2 \%$ by the maternal aunt and the caretaker of the child.
As for the socioeconomic classification, it was observed that most families were in the low superior category (62\%), followed by the medium inferior category $(26 \%)$ and the low inferior one (12\%). In relation to school education, most mothers and fathers had completed high school degree, with $40 \%$ and $26 \%$, respectively.

Among children, $52 \%$ was boys and $48 \%$ girls. As for the data related to school education, it was verified that $96 \%$ of them attended regular school. From these, $90 \%$ was already in the stage of literacy process, whereas the remaining $4 \%$ not yet old enough to join preschool.

In relation to the Speech Language Therapy, $94 \%$ of the subjects attended sessions at least once a week, whereas $6 \%$ of them did not receive any kind of service, with excuses related to difficulties in finding a skilled professional in their city or for judging their children did not need therapy, for they have already developed satisfactory oral language.

On average, the children in the evaluation were 4 years and 3 months of age. As for the sensorial deprivation time, the average among them was 2 years and 3 months of age, and the average age at which the surgery was performed was 2 years and 2 months old, while the time of CI use was about 2 years.

The mean of the threshold frequencies $500 \mathrm{~Hz}, 1 \mathrm{kHz}$, $2 \mathrm{kHz}$, and $4 \mathrm{kHz}$ in open field audiometry for the assessed children was, on average, $26 \mathrm{~dB}$, with minimum response at $20 \mathrm{~dB}$ and maximum response at $50 \mathrm{~dB}$; the SDT had an average of $23 \mathrm{~dB}$, with the minimum value of $20 \mathrm{~dB}$ and the maximum of $50 \mathrm{~dB}$.

The minimum applying time of the instrument was 15 minutes and the maximum time was 35 minutes, with an average of 21 minutes.

Figure 1 describes the results of the questionnaire "Crianças com implante coclear: perspectivas dos pais por subescala", which represents the boxplot of the subscales, considering that the higher the value, the more positive the parental perspective. The lower part of the box indicates the first quartile, in which

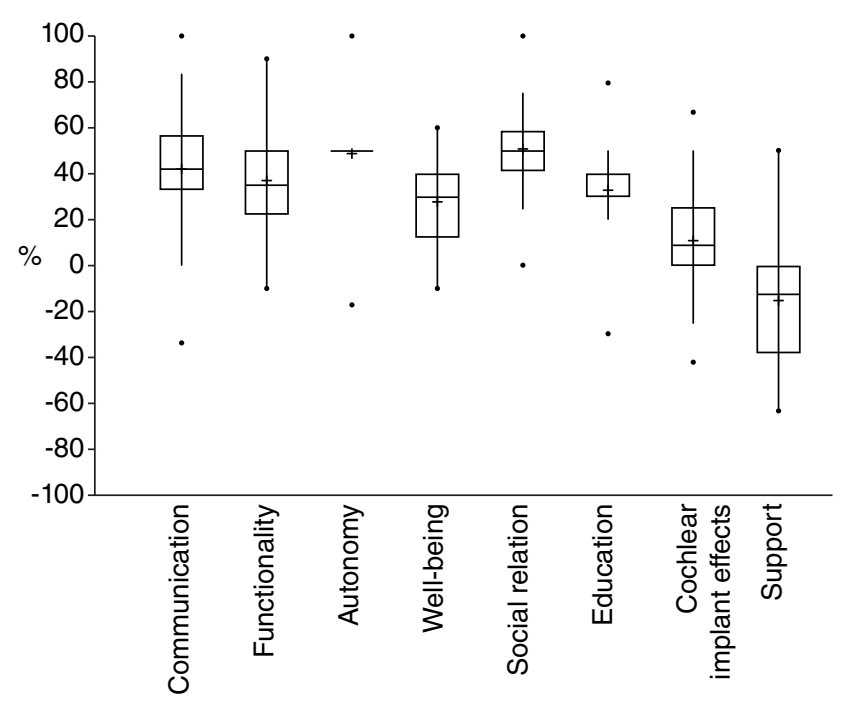

Figure 1. Mean, median, first and third quartiles, and minimum and maximum perception of parents in the subscales of the questionnaire Crianças com implante coclear: perspectivas dos pais, represented by box plots 
$25 \%$ are below the value of Q1, and the upper part, the third quartile, in which $75 \%$ of the percentages are below the value of Q3. The internal horizontal box represents the median. Values higher than Q3 and Q1, represented by score points, above or below the box, are atypical (or possible outliers). The vertical lines indicate the highest and the lowest values observed. The means of the percentages of the subscales are represented in the boxplot by a sign of "plus."

The subscales social relation and autonomy presented the highest median (50\%), followed by communication (41\%), considering the three of them to be related to the child. The functionality obtained a median of $35 \%$ and the subscales well-being and education, $30 \%$. Only the subscale support had a negative score $(-12 \%)$, i.e., the parents evaluated the expectation as for the support to the child negatively.

Table 1 presents the analysis of distribution (\%) between the categories of answers of each subscale to indentify the strength of parental opinion in each item.

Regarding the perspective of parents as for communication, $60 \%$ agree that the children have been developing their oral language, and $68 \%$ stated having been more involved in communicative situations than from before the implant, considering that $74 \%$ of them disagree that communication is difficult between them and known people. From the total, $62 \%$ of them agree they prefer to use oral language rather than sign language to communicate to their children, and for $76 \%$ of them, even in difficult situations of lip reading, such as in the dark, the child can communicate. However, $54 \%$ of parents agreed they are concerned about the amount of speech concerning their child development.

In the subscale functionality, $68 \%$ of parents agree that, before surgery, their children did not present benefits with the devices of individual sound enhance, and $72 \%$ of them stated that their children are currently depending on the CI the whole day long, considering that $66 \%$ of them said their children have fun listening to music, watching TV, or playing video games. However, in this evaluated aspect, $56 \%$ of the parents disagreed to the possibility of allowing their children play outside for being afraid of them not hearing warning signals.

When we evaluated the autonomy of the child, most parents (54\%) agreed that, before the surgery, their kids were too dependent on them, whereas $82 \%$ of them recognized the significant improvement in the self-confidence of the children after CI surgery, and $66 \%$ of them agreed they are as independent as other children. Most of them (82\%) disagreed on not letting them perform activities on their own.

In relation to the well-being and happiness of the child, $64 \%$ of parents felt their children are less frustrated than before the surgery, however, in $22 \%$ of the cases, the frustration still remains.

As for the social relations, $62 \%$ of the parents disagreed their children were socially isolated before the CI, 70\% of them did not agree their children do not make new friends easily, and $58 \%$ that they do not have a close relationship to their grandparents. For $72 \%$ of the parents, the child is sociable within the family and $84 \%$ of them agreed that the relation with the brothers or cousins has improved.
Regarding education, most parents (76\%) disagreed their children are not able to join a regular school, with $52 \%$ of them being happy with their progress. For $72 \%$ of parents, the school fulfills all the needs, and the children have been tagging along; $62 \%$ had concern about their children school future.

For many parents (58\%), regarding CI effects, the progress of the child after $\mathrm{CI}$ have been exceeding their expectations and the communicative skill improved a lot after surgery (74\%).

As for support, $44 \%$ of parents reported helping children more often in the beginning of (re)habilitation, which means that they will need less help later and that, after surgery, $44 \%$ of them have more time for them.

Table 2 presents the results of the correlation between subscales.

A positive significant result between the communication subscale and all the other subscales related to the child and between the communication and subscale referring to family was observed, being the effects of the CI.

Similarly, the subscale school education also presented a significantly positive correlation to the remaining subscales of the family because of the CI effect.

From the subscales of the family, that which represents the effects of the $\mathrm{CI}$ also demonstrated a positive correlation to the subscales communication, school education, and autonomy regarding the child. The subscale support to the child was the only one not to present a significant correlation to any other subscale.

When the correlation between the data of patients and the subscales of the instrument was performed, a significant negative result only from the subscale support to the child at the age of the CI surgery (mean of 2 years and 2 months of age) and the time of sensorial deprivation (mean of 2 years and 3 months of age) was observed, which reflects the opinion of parents that underaged children at the time of the surgery or shorter deafness time need more support, both before and after the surgery.

No other correlation between the patients' data and the aspects approached by the subscales was established.

\section{DISCUSSION}

Nowadays, studies on the evaluation of assistance focused on the perception of population are important and must be absorbed by the services as a way to improve the public system $^{(13)}$. In auditory (re)habilitation, the measures of results have emerged as an effective method to determine whether a specific intervention, such as the $\mathrm{CI}$, is promoting positive results to their users or not ${ }^{(7)}$, which directs the treatment. These measures usually involve the use of questionnaires and allow evaluation of the impact of hearing loss in daily life of children and adults, besides allowing the planning and execution of rehabilitation strategies focused on the needs of people with hearing loss ${ }^{(7)}$.

Besides these aspects, the use of instruments helps professionals keep track of children and their families as for the comprehension of the development of children with CI. Its use allows the family to verify the results and the impact the device has in the life of the child and in their routine activities and, at 
Table 1. Distribution among categories of answers of each subscale of the questionnaire Crianças com implante coclear: perspectivas dos pais

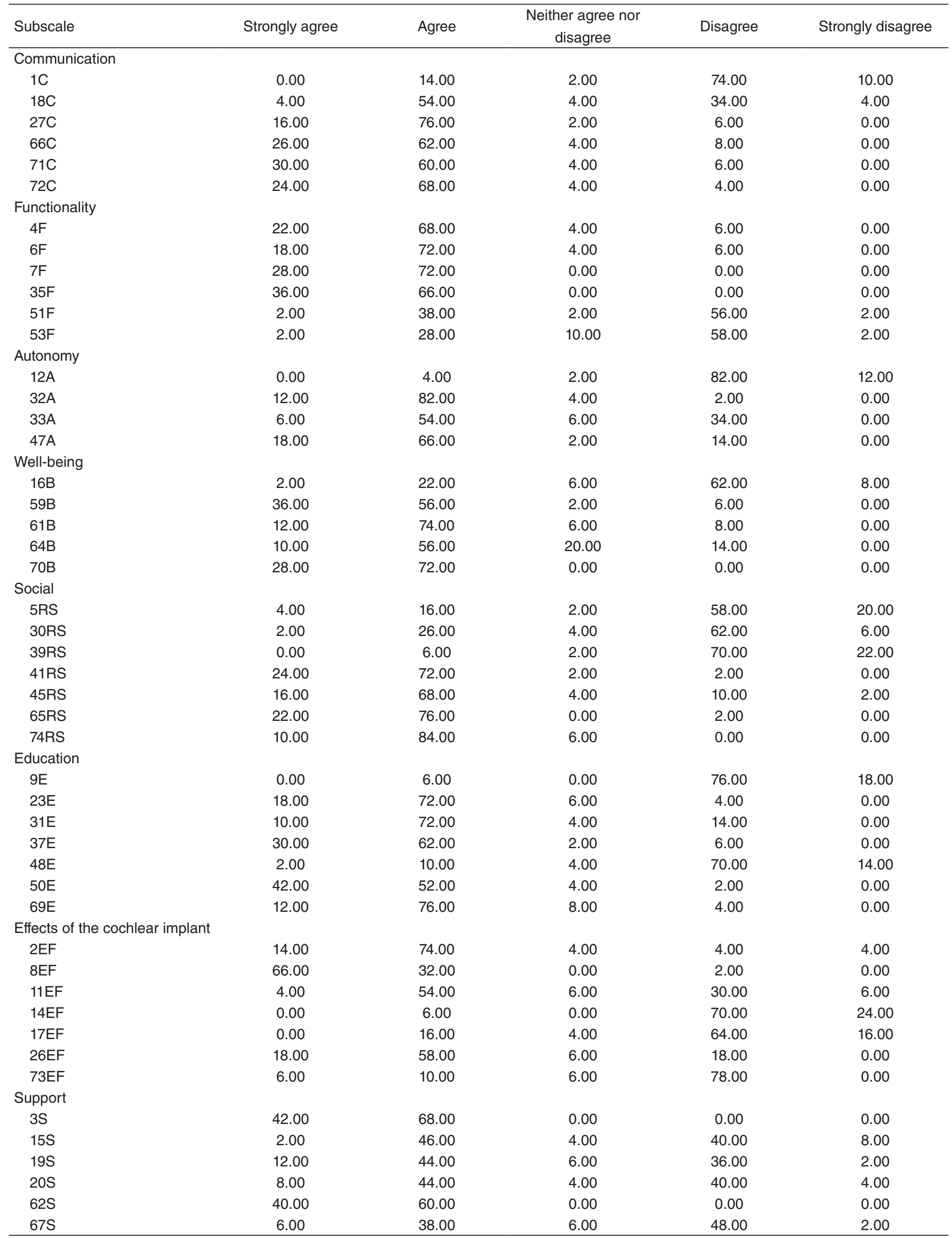


Table 2. Spearman rho correlation coefficients among the subscales of the questionnaire Crianças com implante coclear: perspectivas dos pais

\begin{tabular}{lcc}
\hline Correlations & Rho & p-value \\
\hline Communication and functionality & 0.37 & $0.009^{*}$ \\
Communication and autonomy & 0.62 & $0.000^{\star}$ \\
Communication and well-being & 0.37 & $0.008^{\star}$ \\
Communication and social relation & 0.28 & $0.046^{*}$ \\
Communication and school education & 0.64 & $0.000^{*}$ \\
Communication and effect of the cochlear implant & 0.68 & $0.000^{*}$ \\
Communication and support & 0.09 & 0.532 \\
Functionality and autonomy & 0.43 & $0.002^{*}$ \\
Functionality and well-being & 0.13 & 0.384 \\
Functionality and social relation & -0.01 & 0.950 \\
Functionality and school education & 0.45 & $0.001^{*}$ \\
Functionality and effect of the cochlear implant & 0.18 & 0.212 \\
Functionality and support & -0.16 & 0.266 \\
Autonomy and well-being & 0.20 & 0.164 \\
Autonomy and social relation & 0.40 & $0.004^{\star}$ \\
Autonomy and school education & 0.66 & $0.000^{\star}$ \\
Autonomy and effect of the cochlear implant & 0.29 & $0.039^{\star}$ \\
Autonomy and support & 0.18 & 0.223 \\
Well-being and social relation & 0.45 & $0.001^{*}$ \\
Well-being and school education & 0.30 & $0.032^{*}$ \\
Well-being and effect of the cochlear implant & 0.25 & 0.085 \\
Well-being and support & 0.27 & 0.055 \\
Social relation and school education & 0.37 & $0.009^{*}$ \\
Social relation and effect of the cochlear implant & 0.10 & 0.489 \\
Social relation and support & 0.24 & 0.097 \\
School education and effect of the cochlear implant & 0.32 & $0.024^{\star}$ \\
School education and support & 0.12 & 0.409 \\
Effect of the cochlear implant and support & 0.04 & 0.779 \\
\hline & & \\
\hline
\end{tabular}

*Statistically significant.

the same time, allow the monitoring of their development steps in their process of hearing skills and oral language acquisition $^{(4,5)}$, helping in the adequacy of the therapeutical treatment in the objectives of rehabilitation.

In Brazil, the use of these instruments with children is not widespread. However, in other countries, the use of this resource with parents and caregivers is already a common practice $^{(14)}$. Some studies have been describing the parental point of view on the implant process, finding as a result concerns in relation to this experience ${ }^{(15-18)}$. Other researches consider the perception of parents as for the results obtained by children with $\mathrm{CI}^{(18,19)}$.

In this study, despite most patients belonging to the superior lower socioeconomic class, according to the proposed classification $^{(20)}$, many of them have complete high school education, which reflects in good comprehension during the use of the instrument. Studies report that the low school education of the Brazilian population may hinder the proper comprehension of the questionnaires, leaving as optional the authors' helping the participants in their reading. Besides that, on average, the instrument took only 21 minutes to be filled out and, therefore, was able to be used in clinical routine, with the objective of evaluating the perspectives and expectations of parents.
Regarding the results of the questionnaire, when verifying and comparing the medians of each subscales, the most satisfying expectations were on the aspects evaluated by the subscales social relations, autonomy, and communication, whereas support to the child had the lowest score. This reveals that the better the child's oral language, the better is their interaction to friends and family, their independency, and autonomy, which implies in less support by parents after CI. Other studies reached the same conclusion, as is the case of a study carried out in Brazil, which found similar results in the subscales autonomy and social relations ${ }^{(10)}$.

Thus, most parents considered their children more independent after the surgery. The positive evaluation as for these aspects is related to their hearing ability; therefore, the CI allows children to socially participate in educational environments, developing their self-confidence ${ }^{(21,22)}$.

In this study, although the children have been developing their oral language after the CI surgery, many parents reported concerns regarding the quality of their children's speech, similar to other studies ${ }^{(4,15,21,23)}$. It is known that the intelligibility of speech is developed in a longer temporal scale than the perception of speech, improving throughout the years after the CI surgery ${ }^{(24)}$, being possible that the quality of speech of these children may improve over time. Thus, it is necessary to orient parents about this fact, besides guiding rehabilitation toward working this aspect.

The subscales communication and CI effects were the ones presenting higher numbers of significant correlations to the others. This demonstrates how much the acquisition and development of oral language are related to the development of other skills, leading to positive effects in the implementation in the parental point of view ${ }^{(3,10)}$.

For future research, it would be interesting to compare whether children who received bilateral CI will have the benefits related to quality of health in lesser time of use of the device ${ }^{(25)}$. This way, parents whose children received the CI may offer valuable comments for the implant teams. They offer not only reliable information on the children but also a perspective of the implant process, additional necessary intervention, and the benefits and limitations experienced. These collected data are precious to help the team monitoring both family and child, especially right after CI, in which doubts are more frequent, serving as a basis for guidance and clarifications of parents by the professionals.

\section{CONCLUSION}

The evaluation of the perceptions and expectations of parents in relation to the development of children using $\mathrm{CI}$ in this study allowed the conclusion that:

- Parents have good expectation in relation to the independence/autonomy of the child;

- Parents are satisfied with the social participation and communication of their children after the CI surgery;

- For parents, children have been progressing in school;

- Worries about the quality of the speech of their children still remain. 
*MRS was responsible for the elaboration of the project, collection, and tabulation of the data, organization of the data in tables, discussion of the results, literature survey, and writing of the manuscript; MM collaborated to the elaboration of the project, the tabulation and the statistical analysis of the data, the discussion of the results, and the writing of the manuscript; JSZ collaborated to the statistical analysis of the data and the organization and writing of the manuscript, in addition to the literature survey and the organization of the literature for inclusion in the manuscript; MCB was responsible for the project and its design together with the author MRS and guided the general steps, such as the descriptive and statistical analysis of the data, the elaboration of discussion and results, and the writing of the manuscript; ALMM supervised the collection of the data, collaborating to the descriptive and statistical analysis of the data and participating on the elaboration of the discussion of results and the writing of the manuscript.

\section{REFERENCES}

1. Lin FR, Niparko JK. Measuring health-related quality of life after pediatric cochlear implantation: a systematic review. Int J Pediatr Otorhinolaryngol. 2006;70(10):1695-706.

2. Goycoolea MV, Latin American Cochlear Implant Group. Latin American experience with the cochlear implant. Acta Otolaryngol. 2005;125(5):468-73.

3. Huttunen K, Rimmanen S, Vikman S, Virokannas N, Sorri M, Archbold S, et al. Parents' views on the quality of life of their children 2-3 years after cochlear implantation. Int J Pediatr Otorhinolaryngol. 2009;73(12):1786-94.

4. Incesulu A, Vural M, Erkam U. Children with cochlear implants: parental perspective. Otol Neurotol. 2003;24(4):605-11.

5. Hashemi SB, Monshizadeh L. The quality of life in pre-lingual deaf children after 1.5 years of cochlear implantation from the point of view of parents in Shiraz, Iran. Iranian Red Crescent Medical Journal. 2011;13(6):431-3.

6. Damen GW, Krabbe PF, Archbold SM, Mylanus EA. Evaluation of the Parental Perspective instrument for pediatric cochlear implantation to arrive at a short version. Int J Pediatr Otorhinolaryngol; 2007;71(3):425-33.

7. Cox RM, Alexander GC. Measuring satisfaction with amplification in daily life: the SADL scale. Ear Hear. 1999;20(4):306-20.

8. Archbold SM, Lutman ME, Gregory S, O'Neill C, Nikolopoulos TP. Parents and their deaf child: their perceptions three years after cochlear implantation. Deafness and Education International. 2002;4(1):12-40.

9. O'Neill C, Lutman ME, Archbold SM, Gregory S, Nikolopoulos TP. Parents and their cochlear implanted child: questionnaire development to assess parental views and experiences. Int J Pediatr Otorhinolaryngol. 2004;68(2):149-60.

10. Fortunato-Tavares T, Befi-Lopes D, Bento RF, Andrade CRF. Crianças com implante coclear: habilidades comunicativas e qualidade de vida. Braz J Otorhinolaryngol. 2012;78(1):15-25.
11. Zaidman-Zait A, Most T. Cochlear implants in children with hearing loss: maternal expectations and impact on the family. Volta Review. 2005;105:129-50.

12. Cheng AK, Niparko JK. Cost-effectiveness of the cochlear implant in children. Cochlear implantation: cost creating or cost saving? Proceedings of Conference on Health Technology Assessment. Oxford, UK: Hughes Associates; 2001. p. 111-9.

13. Paiva DCP, Bersusa AAS, Escuder MML. Avaliação da assistência ao paciente com diabetes e/ou hipertensão pelo Programa Saúde da Família do Município de Francisco Morato, São Paulo, Brasil. Cad Saúde Pública. 2006;22(2): 377-85.

14. Souza MR, Osborn E, Gil D, Iório MC. Translation and adaptation of the ABEL: Auditory Behavior in Everyday Life questionnaire into Brazilian Portuguese. J Soc Bras Fonoaudiol. 2011;23(4):368-75.

15. Nikolopoulos TP, Lloyd H, Archbold S, O'Donoghue GM. Pediatric cochlear implantation: the parents' perspective. Arch Otolaryngol Head Neck Surg. 2001;127(4):363-7.

16. Spahn C, Burger T, Löschmann C, Richter B. Quality of life and psychological distress in parents of children with a cochlear implant. Cochlear Implants Int. 2004;5(1):13-27.

17. Burger T, Spahn C, Richter B, Eissele S, Löhle E, Bengel J. Parental distress: the initial phase of hearing aid and cochlear implant fitting. Am Ann Deaf. 2005;150(1):5-10.

18. Weisel A, Most T, Michael R. Mothers' stress and expectations as a function of time since child's cochlear implantation. J Deaf Stud Deaf Educ. 2007;12(1):55-64.

19. Lin FR, Wang NY, Fink NE, Quittner AL, Eisenberg LS, Tobey EA, et al. Assessing the use of speech and language measures in relation to parental perceptions of development after early cochlear implantation. Otol Neurotol. 2008;29(2):208-13.

20. Graciano MIG, Pavão APAR, Blattner SHB. Os indicadores de estudo sócio econômico na construção do relatório social no Hospital de Reabilitação de Anomalias Craniofaciais. Serviço Social \& Saúde. 2006;5:183-216.

21. Archbold S, Sach T, O'Neill C, Lutman M, Gregory S. Outcomes from cochlear implantation for child and family: parental perspectives. Deafness and Education International. 2008;10(3):120-42.

22. Nicholas JG, Geers AE. Personal, social, and family adjustment in school-aged children with a cochlear implant. Ear Hear. 2003;24(1 Suppl):69S-81S.

23. Sach TH, Whynes DK. Paediatric cochlear implantation: the views of parents. Int J Audiol. 2005;44(7):400-7.

24. Beadle EA, McKinley DJ, Nikolopoulos TP, Brough J, O'Donoghue GM, Archbold SM. Long-term functional outcomes and academicoccupational status in implanted children after 10 to 14 years of cochlear implant use. Otol Neurotol. 2005;26(6):1152-60.

25. Scherf F, Van Deun L, van Wieringen A, Wouters J, Desloovere C, Dhooge I, et al. Subjective benefits of sequential bilateral cochlear implantation in young children after 18 months of implant use. ORL J Otorhinolaryngol Relat Spec. 2009;71(2):112-21. 